\title{
Meta-analysis of the role of zinc in coordinating absorption of mineral elements in wheat seedlings
}

\author{
Xiaolong Guo ${ }^{1 \dagger}$, Xiangyu Ma ${ }^{1 \dagger}$, Jialiang Zhang ${ }^{1}$, Jinghuan Zhu², Tian Lu', Qifei Wang ${ }^{2}$, Xiaoming Wang ${ }^{1}$,
} Wei Hua ${ }^{2^{*}}$ and Shengbao $\mathrm{Xu}^{1^{*}}$ (D)

\begin{abstract}
Background: Zinc (Zn) is an important nutrient for human beings, which is also an essential micronutrient for crop growth. This study investigated the role of $\mathrm{Zn}$ in coordinating the mineral elements absorption in modern wheat (Triticum aestivum L.) cultivars with a new developed method.

Results: A method was developed, and showed a robust capability to simultaneously investigate seven mineral elements uptake in wheat seedling. With this method, we found low Zn supply $(<1 \mu \mathrm{M})$ promoted the absorption of potassium (K), magnesium (Mg) and manganese (Mn) in wheat seedling, while high Zn supply (> $1 \mu \mathrm{M})$ significantly inhibited the absorption of these elements. Cultivars with the green genes (Rht-B1b and Rht-D1b) showed a higher uptake capability on ammonium $\left(\mathrm{NH}_{4}{ }^{+}\right)$, and cultivars with $R h t-B 1 b$ allele can uptake more phosphors $(\mathrm{P}), \mathrm{K}$, calcium (Ca), Mn and Zn compared to cultivars with Rht-D1b. Further analysis indicated higher uptake capability of $\mathrm{NH}_{4}{ }^{+}$in cultivars contained Rhts was independent of $Z n$.

Conclusion: The key role of $\mathrm{Zn}$ in coordinating for mineral elements absorption was identified in modern wheat cultivars, providing the reference for $\mathrm{Zn}$ application in wheat. Meanwhile, this study provides a robust method for quantifying the absorption of mineral elements, which may be adopted into the broadly investigations on the coordinated nutrients absorption of plant.
\end{abstract}

Keywords: Wheat, Zinc, Mineral elements absorption, New method, Cultivars

\section{Background}

To enhance the yield, chemical fertilizer has become the main source of mineral elements for all kinds of crops $[1,2]$. While these inputs help to meet the demand for crop yields, then overuse of fertilizers also causes serious environmental damage, such as the greenhouse effect and water eutrophication [3]. Therefore, it is important

\footnotetext{
*Correspondence: huaweicau@hotmail.com; xushb@nwsuaf.edu.cn

${ }^{+}$Xiaolong Guo and Xiangyu Ma contributed equally to this work

1 State Key Laboratory of Crop Stress Biology for Arid Areas, College of Agronomy, Northwest A\&F University, Yangling, Xianyang 712100,

Shaanxi, China

${ }^{2}$ Zhejiang Academy of Agricultural Sciences, Hangzhou 310021,

Zhejiang, China
}

to understand the mineral element absorption rules of crops for rational fertilization.

$\mathrm{Zn}$ is an essential nutrient element for plants and humans, which is widely involved in biochemical and physiological processes, including enzyme activity, cell division, photosynthesis, carbohydrate and lipid metabolism, detoxification of oxygen radicals and protein synthesis [4-7]. Zn deficiency is common in most crops, which causes leaf chlorosis, curling and wilting, and stunted and thin stems [8-10], and ultimately leads to low grain yields and poor grain quality [11,12]. Foliar application of $\mathrm{Zn}$ can be absorbed through the cuticle and/or the stomates, and then transported to leaves, stems, reproductive tissues and grains, to rescue the symptom of $\mathrm{Zn}$ deficiency original author(s) and the source, provide a link to the Creative Commons licence, and indicate if changes were made. The images or other third party material in this article are included in the article's Creative Commons licence, unless indicated otherwise in a credit line to the material. If material is not included in the article's Creative Commons licence and your intended use is not permitted by statutory regulation or exceeds the permitted use, you will need to obtain permission directly from the copyright holder. To view a copy of this licence, visit http://creativecommons.org/licenses/by/4.0/. The Creative Commons Public Domain Dedication waiver (http://creativeco mmons.org/publicdomain/zero/1.0/) applies to the data made available in this article, unless otherwise stated in a credit line to the data. 
$[13,14]$. Proper supply $\mathrm{Zn}$ can promote plant growth and development by enhancing photosynthesis and carbohydrate metabolism [15]. On the other side, excess $\mathrm{Zn}$ can lead to leaf necrosis [16], biomass decline [17], affect the absorption of other elements [18] and many adverse effects on crop growth and development $[5,19]$. Previous studies focused on the effects of other elements on $\mathrm{Zn}$ uptake in crops [20-22]. However, the effect of $\mathrm{Zn}$ in regulating other mineral elements absorption is still largely unknown, which hinders our understanding of the rational use of $\mathrm{Zn}$ fertilizer in agricultural production.

The commonly application of dwarfing genes $R h t-B 1 b$ and Rht-D1b significantly increases modern wheat yield and the high-input of nitrogen fertilizers is the key to achieve the maximum its yield potential [23-26]. Previous studies have shown that Rhts allele significantly altered iron $(\mathrm{Fe}), \mathrm{Zn}$, copper $(\mathrm{Cu})$ and $\mathrm{Mg}$ content in wheat grains $[24,27]$, then the underlying mechanism still keeps in largely unknown.

At present, the research on nutrient elements absorption in crops mainly adopts tissue digestion method to determine the content of mineral elements in plant tissues [24, 28, 29]. However, this method is relatively tedious and also has the risk because of the strong acid application. Therefore, the aim of this study was to develop a new method for quantifying the absorption of mineral elements and identify the role of $\mathrm{Zn}$ in the coordinated absorption of mineral elements in wheat seedling.

\section{Results}

\section{A new method for quantifying mineral elements uptake} in wheat seedling

To investigate the mineral elements uptake in wheat seedling, a nutrient solution quantification in the test tube was developed. Briefly, hydroponic wheat seedling (14 days after germination) was transferred to the tube containing $1 / 2$ Hoagland nutrient solution with different treated time (Fig. 1), then quantifying the reduction of mineral elements in solution by atomic absorption spectrophotometer and continuous flow analyzer, to represent the uptake by the wheat seedling.

To evaluate the reliability of this method and determine the optimal treatment time, two wheat cultivars and four treatment times $(12 \mathrm{~h}, 36 \mathrm{~h}, 60 \mathrm{~h}, 84 \mathrm{~h})$ were selected for the evaluation. The absorption of the all three elements $\left(\mathrm{NH}_{4}{ }^{+}, \mathrm{P}\right.$ and $\left.\mathrm{K}\right)$ increased with the treatment duration, and showed significant difference in absorption between two tested cultivars (Fig. 2a). Meanwhile, the contents of three elements in the control tube remained constant at any quantification time (Additional file 1: Figure S1), indicating the mineral elements were absorbed in wheat seedlings, and the quantification procedure is reliable. To

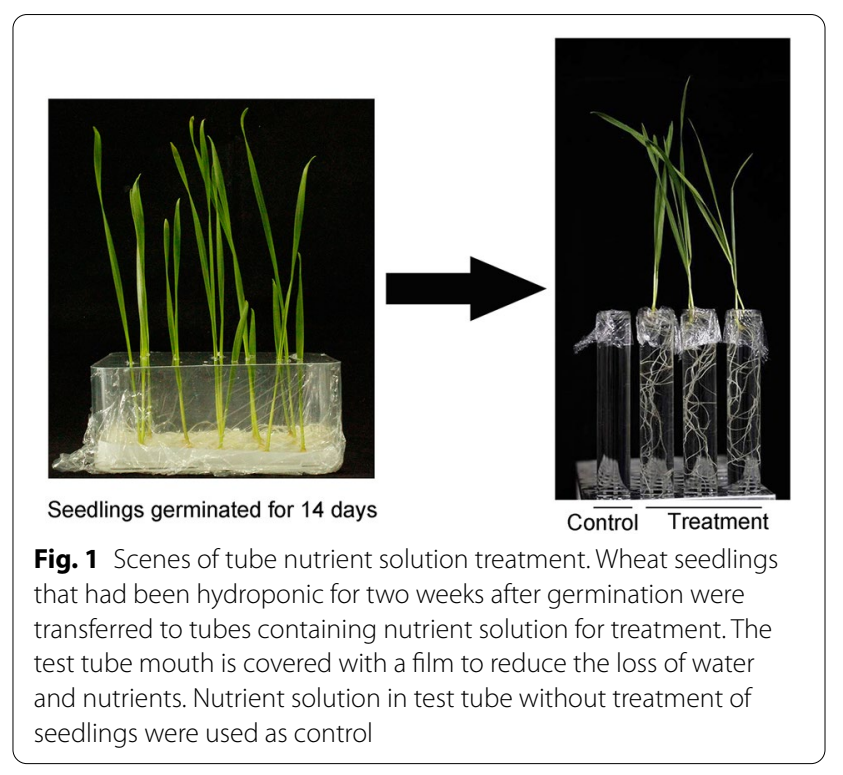

determine the optimal treatment time point, the absorption rates of three elements were analyzed (Fig. 2b) and showed that the absorption rate of three elements gradually decreased with the treatment duration, and then plateaued at $60 \mathrm{~h}$. In addition, the absorption of $\mathrm{Mg}, \mathrm{Ca}$, $\mathrm{Mn}$ and $\mathrm{Zn}$ in wheat seedling could also showed a stable value after $60 \mathrm{~h}$ treatment (Additional file 1: Figure S2). Therefore, $60 \mathrm{~h}$ treatment was selected for subsequent investigations.

\section{Correlation of absorption of seven mineral elements in wheat seedling}

To understand the coordinated absorption of different elements in wheat seedling, a correlation analysis was performed (Fig. 3), and showed a significant positive correlation among the five macronutrients $(\mathrm{N}, \mathrm{P}, \mathrm{K}, \mathrm{Mg}$ and $\mathrm{Ca})$, consistent with the previous reports [30,31]. A new finding is that trace element $\mathrm{Zn}$ is significantly positive correlated with macronutrients $\mathrm{N}, \mathrm{K}, \mathrm{Mg}$ and trace element $\mathrm{Mn}$, indicating that $\mathrm{Zn}$ plays an important role in mediating nutrient absorption of wheat.

\section{Zn significantly affects the uptake of other mineral elements in wheat seedling}

To further clarify the role of $\mathrm{Zn}$ in mediating mineral elements absorption, five $\mathrm{Zn}$ concentrations were performed on seven wheat cultivars. Results showed the uptake of $\mathrm{Zn}$ in all seven cultivars is significantly increased with the increase of $\mathrm{Zn}$ concentration (Additional file 1: Figure S3). In different $\mathrm{Zn}$ concentrations, the absorption of $\mathrm{K}, \mathrm{Mg}$ and $\mathrm{Mn}$ in all seven wheat cultivars is promoted by low concentration $\mathrm{Zn}(<1 \mu \mathrm{M})$ but is inhibited by the high concentration $(10 \mu \mathrm{M})$, and 


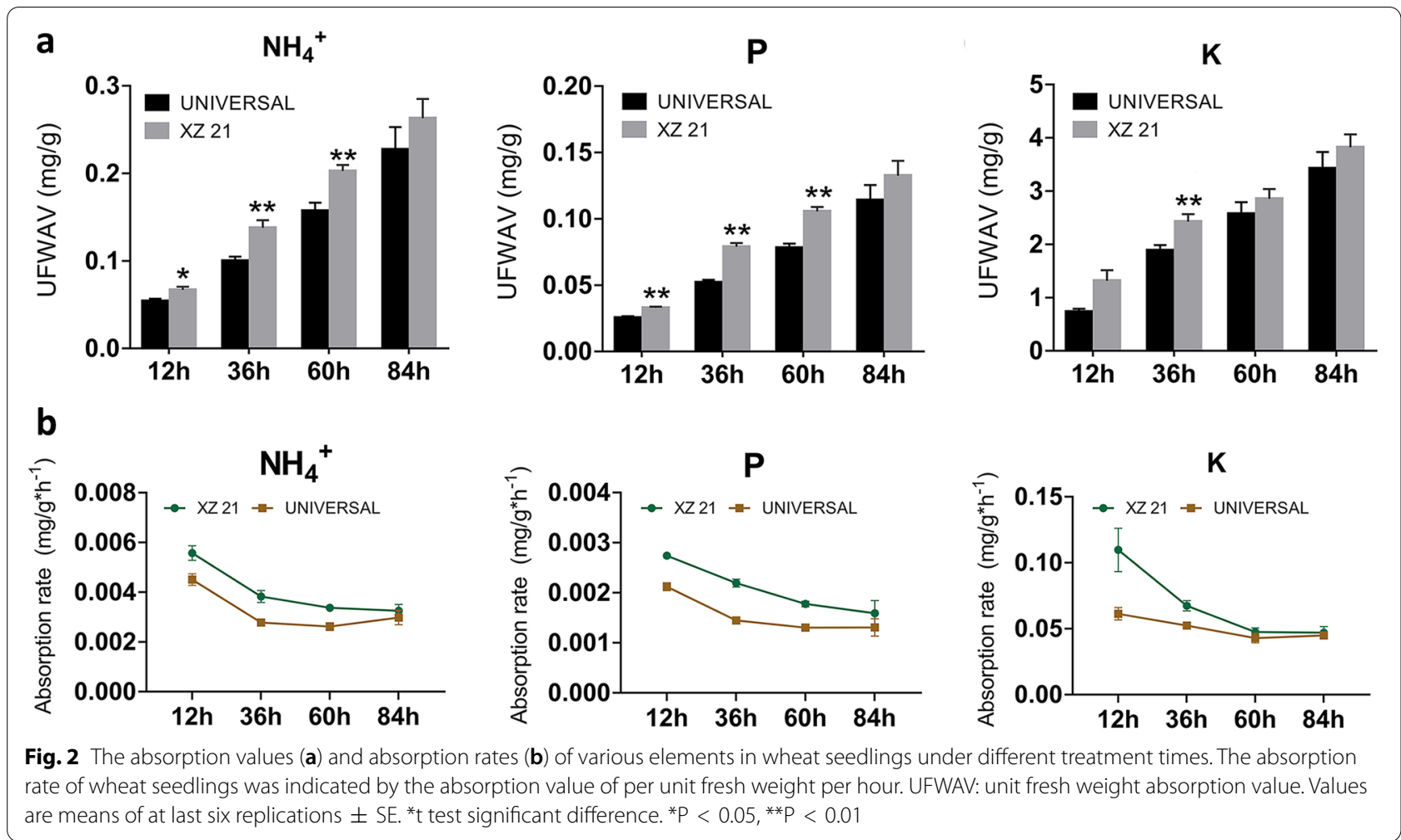

suggesting $0.01-0.1 \mu \mathrm{M} \mathrm{Zn}$ in solution have the optimal effect to promote the uptake of other mineral elements (Fig. 4). However, the uptake of $\mathrm{NH}_{4}{ }^{+}$and $\mathrm{P}$ seems not be affected by different Zn supply (Fig. 4). These results displayed the role of $\mathrm{Zn}$ in regulating the absorption of specific mineral elements in wheat seedling.

Interestingly, the uptake of $\mathrm{Ca}$ showed distinct response among different cultivars with the alterations of $\mathrm{Zn}$ concentration (Fig. 4), indicating the interaction between $\mathrm{Zn}$ and $\mathrm{Ca}$ uptake is highly variable in different wheat cultivars, which may be determined by the different genetic background of different wheat cultivar.

\section{The potential role of dwarfing gene Rhts in mineral elements uptake}

Previous studies suggested that the dwarfing gene $R h t s$ significantly increases the uptake for nitrogen fertilizer in crops [26, 32]. To further test our method, eight new wheat cultivars were added into our investigation. All fifteen wheat cultivars (see methods) were classified into three groups: $R h t-B 1 b$ allele contained group, $R h t$ $D 1 b$ allele contained group and Control group (without either $R h t-B 1 b$ or $R h t-D 1 b$ allele). We found the uptake of $\mathrm{NH}_{4}{ }^{+}$is significantly increased in both $R h t-B 1 b$ and $R h t-D 1 b$ group (Fig. 5) with medium Zn supply ( $1 \mu \mathrm{M})$, consistent with previous conclusion [23], further supporting the special role of green gene in mineral elements absorption.

In addition, $R h t-B 1 b$ showed a significantly higher uptake of $\mathrm{P}, \mathrm{K}, \mathrm{Ca}$ and $\mathrm{Mn}$ compared to control group, and a higher absorption in $\mathrm{P}$ and $\mathrm{Zn}$ compared to Rht$D 1 b$ group (Fig. 5). However, neither $R h t-B 1 b$ nor $R h t$ $D 1 b$ significantly affected $\mathrm{Mg}$ absorption (Fig. 5). These results indicate that $R h t$ s alleles contribute a broad effect in the absorption of mineral elements in addition to nitrogen, and suggest a different mineral element uptake potential between $R h t-B 1 b$ and $R h t-D 1 b$.

\section{The interaction between $\mathrm{Zn}$ supply and $R$ hts alleles on uptake of mineral elements}

In low $\mathrm{Zn}$ concentration $(<1 \mu \mathrm{M})$, both $R h t-B 1 b$ and $R h t$ $D 1 b$ group showed a significantly increased absorption on $\mathrm{NH}_{4}{ }^{+}$with the $\mathrm{Zn}$ supply increase, and $R h t-B 1 b$ and $R h t-D 1 b$ group showed enhanced absorption of $\mathrm{P}$ and $\mathrm{Mg}$, respective (Additional file 1: Figure S4). While the $R h t-D 1 b$ group showed a significantly decreased absorption on $\mathrm{Ca}$ and $\mathrm{Mn}$ with $\mathrm{Zn}$ supply increase (Additional file 1: Figure S4).

In high $\mathrm{Zn}$ concentration $(10 \mu \mathrm{M}), R h t-B 1 b$ and $R h t-D 1 b$ group still maintained the higher absorption on $\mathrm{NH}_{4}{ }^{+}$compared control group (Fig. 6), indicating that the higher $\mathrm{NH}_{4}{ }^{+}$absorption is independent of $\mathrm{Zn}$ concentration. Similarly, the absorption of P, K, 


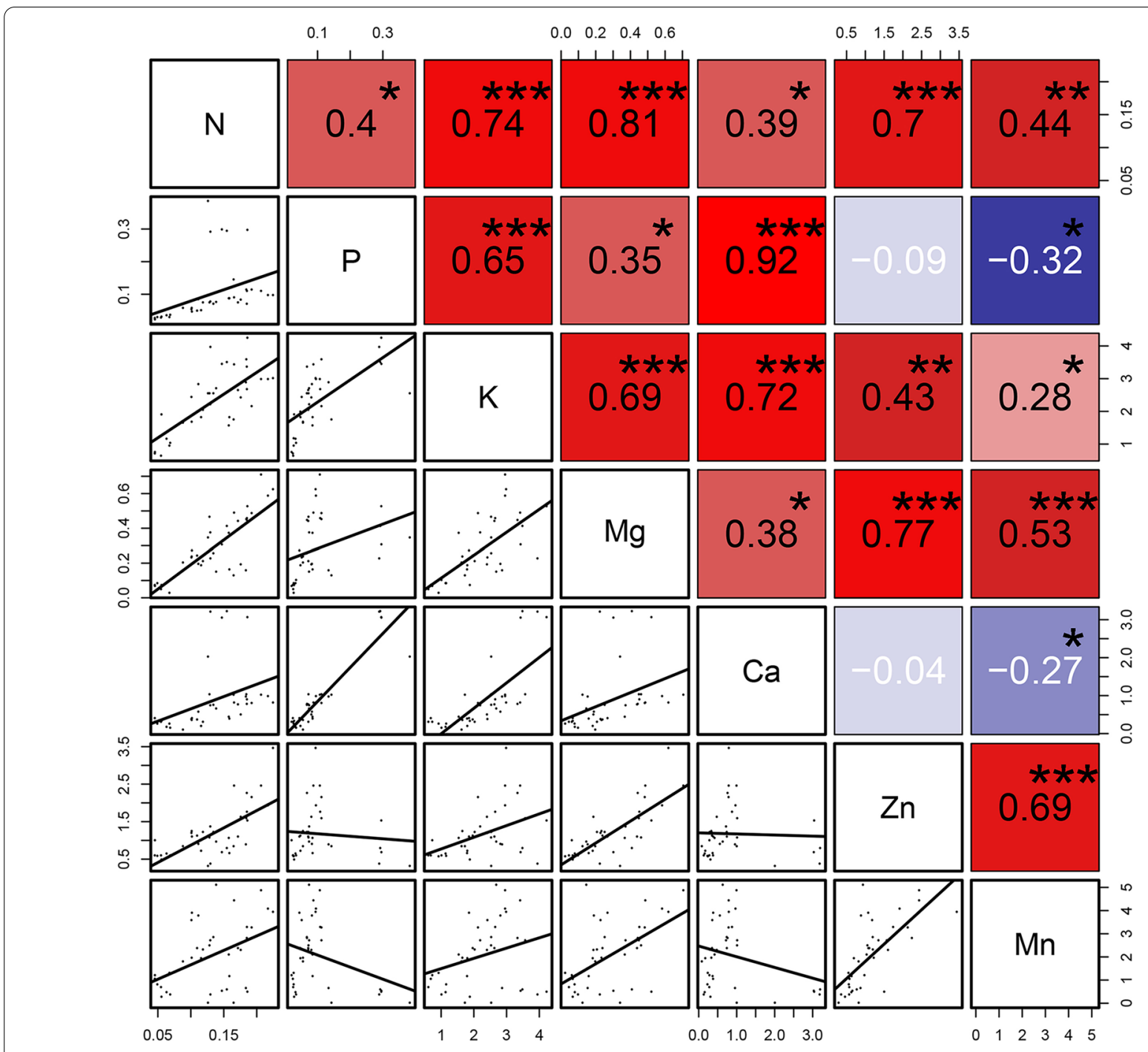

Fig. 3 Pearson correlation analysis matrix between elements. ${ }^{*}$ Significant correlation. ${ }^{*} P<0.05,{ }^{* * P}<0.01,{ }^{* *} P<0.001$. The fitting function are shown in Additional file 2: Table S1

$\mathrm{Ca}, \mathrm{Mg}, \mathrm{Mn}$ was not significantly inhibited by high $\mathrm{Zn}$ concentration in Rht-D1b group (Fig. 6), compared to the absorption in medium $\mathrm{Zn}$ concentration (Fig. 5). In contrast, the absorption of these elements was significantly inhibited in $R h t-B 1 b$ and control group, highlighting a special interaction between $\mathrm{Zn}$ and $R h t-D 1 b$ in mineral elements absorption.

\section{Discussion}

In this study, we developed a new method to quantify the absorption of mineral elements in wheat seedling. Our data with this method demonstrated highly stable and reproducible, indicating it is a robust method, which could be applied to study the role of different elements in wheat nutrient coordinated absorption, and may be extend to other crops.

Although its robustness, there are still some disadvantages that should not be overlooked. Firstly, the $\mathrm{NO}_{3}{ }^{-}$ ions, another important nitrogen form [33], failed to be quantified in this method. Secondly, few trace elements cannot be effectively detected due to their low content nature. Thirdly, the soil environments and related microorganism context played the core role in determining the absorption of soil mineral elements [34, 35], thus this method definitely need further evaluate and improve to reflect the real status of nutrients uptake by crop in field condition. Then based on this initial method here, it is promised to develop a comprehensive and precise method for futural study in plant nutrients absorption. 

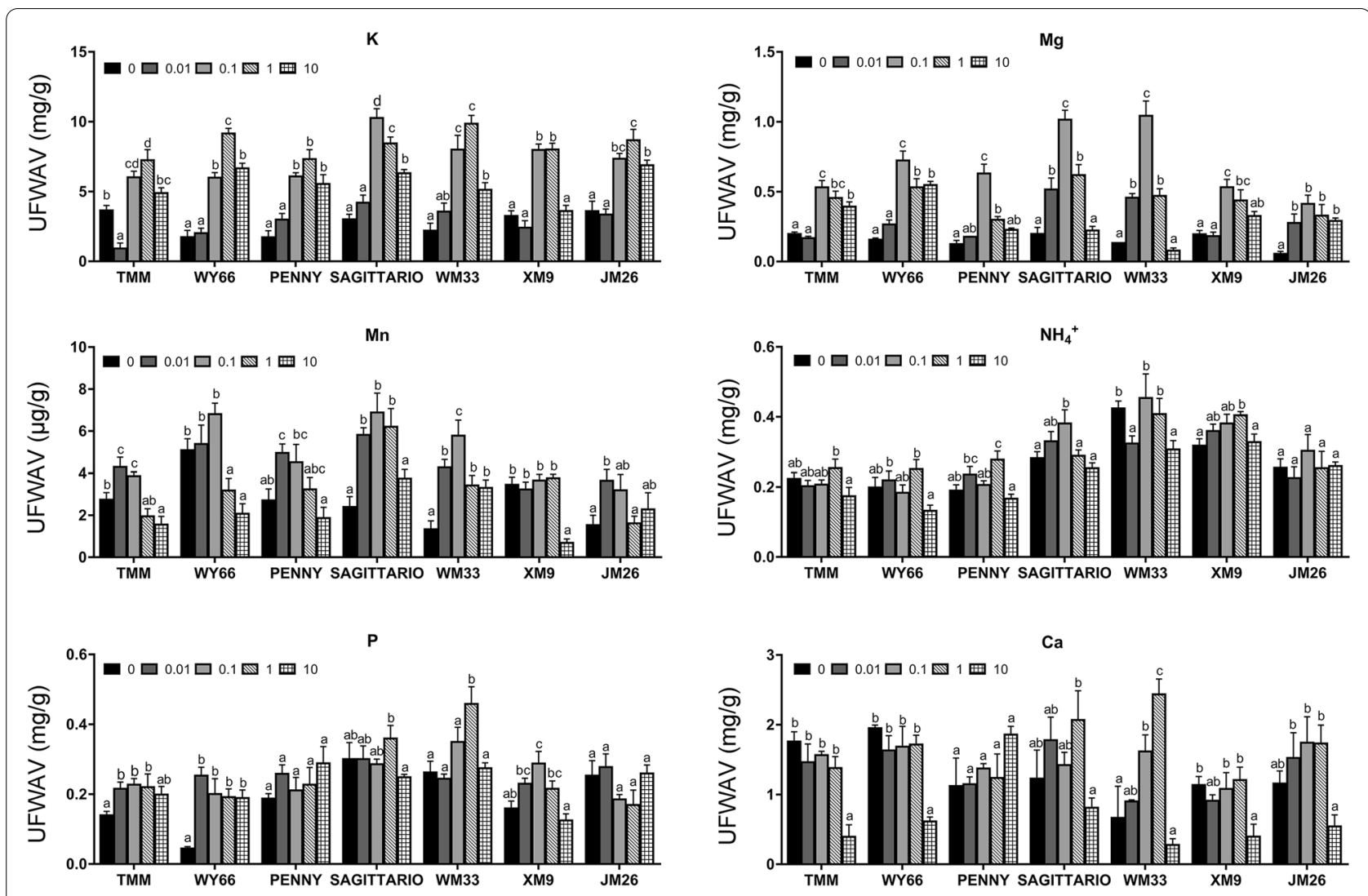

Fig. 4 Effects of different Zn concentrations on the absorption of mineral elements in wheat seedlings. UFWAV: unit fresh weight absorption value. Values are means of at least six replications \pm SE. Within each cultivar, means with different lowercase letters are significantly different at $P<0.05$

In this study, our results (Fig. 4) indicate that $\mathrm{Zn}$ broadly affects $\mathrm{K}, \mathrm{Mg}$, and $\mathrm{Mn}$ uptake, supporting low concentration of $\mathrm{Zn}$ limited the absorption of $\mathrm{K}$ and $\mathrm{Mg}$ $[12,36]$ and high concentration of $\mathrm{Zn}$ significantly inhibits the absorption of $\mathrm{Mn}$ and $\mathrm{Ca}$ [37-39]. This result further confirms that excessive $\mathrm{Zn}$ caused a negative interferences to others nutrients uptake [16]. It should be noted that the absorption of $\mathrm{NH}_{4}^{+}$in different $\mathrm{Zn}$ concentrations keeps stable in this study (Fig. 4d), which is different with the positive interaction relationship between $\mathrm{Zn}$ and nitrogen in previous report [40]. We assume the difference may result from the quantification on uptake of nitrate is missed in our study, but this hypothesis needs further comprehensive investigation. Importantly, a general optimum concentration of $\mathrm{Zn}$ was proposed, the $0.01-0.1 \mu \mathrm{M}$ of $\mathrm{Zn}$ in solution can promote the uptake of most mineral elements, providing a reference concentration for futural $\mathrm{Zn}$ fertilizer application.

Consistent with the previous study [23], both $R h t-B 1 b$ and $R h t-D 1 b$ significantly increased $\mathrm{NH}_{4}^{+}$uptake by wheat seedling. Moreover, in our results $R h t-B 1 b$ and $R h t-D 1 b$ contribute a distinct influence in the uptake of mineral elements, and distinct response to alteration of $\mathrm{Zn}$ concentrations. Although limited wheat cultivars were investigated in this study, then these distinct responses between the $R h t-B 1 b$ and $R h t-D 1 b$ implying that our method may provide important clues for studying the effect of different genes on the mineral element absorption in plant.

\section{Conclusions}

In summary, the new method developed in this study have a robust capability to investigate the coordinated mineral elements absorption in wheat seedling, and promisingly extend to other crops. With this method, we identified the key role of $\mathrm{Zn}$ in coordinated absorption of mineral elements in wheat seedling, which provides a reference to properly apply $\mathrm{Zn}$ for enhancing wheat production.

\section{Methods}

\section{Plant materials}

In this study, according to whether it contained $R h t-B 1 b$ and $R h t-D 1 b$ alleles, fifteen wheat cultivars were used and divided into three groups: Control group: UNIVERSAL, Chuannong12 (CN12), Nanda96co76 (ND96), 

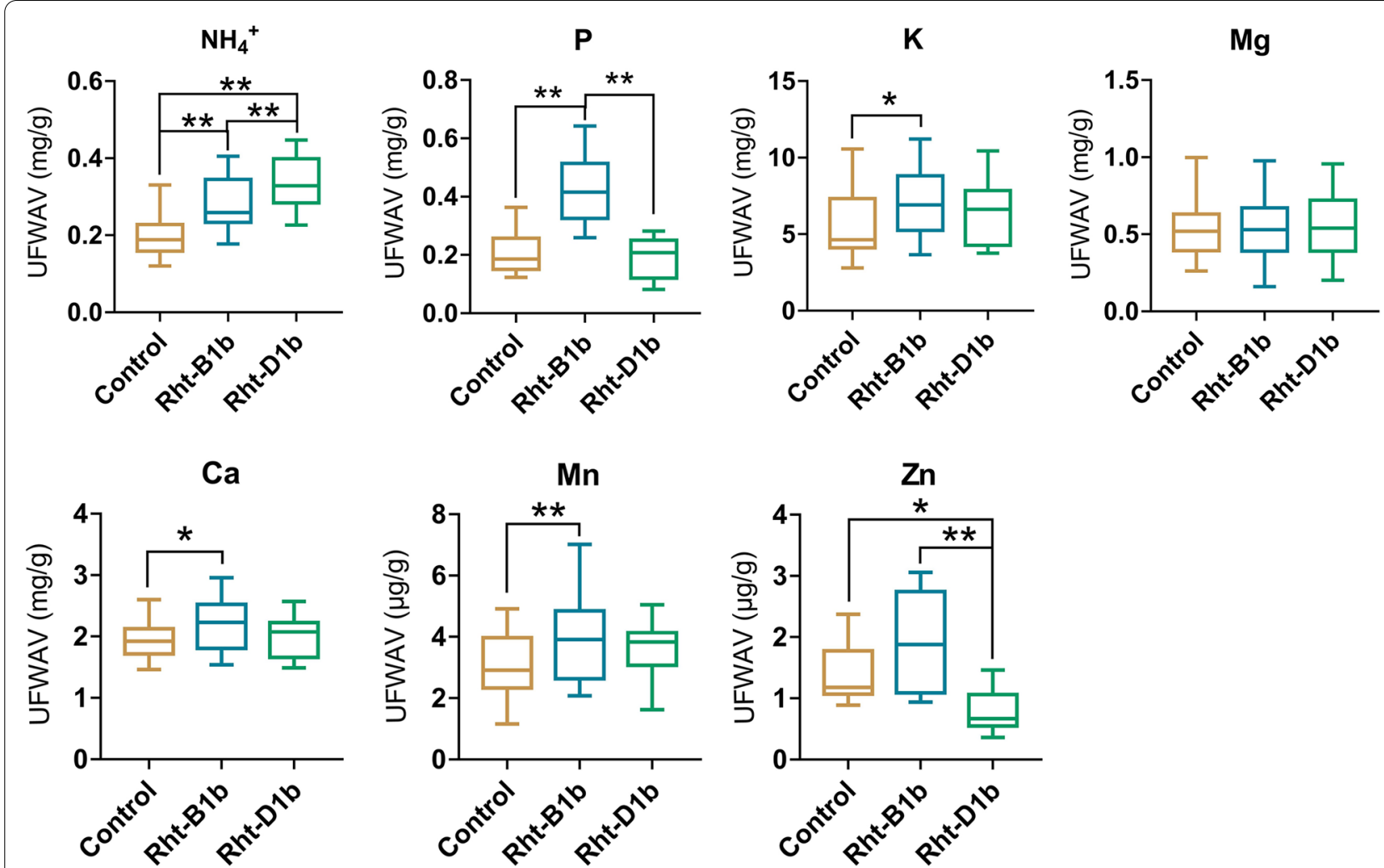

Fig. 5 Effects of Rhts allele on absorption of mineral elements in wheat. UFWAV: unit fresh weight absorption value. The control group contains seven cultivars, and the Rht-B1b and Rht-D1b groups respectively include four cultivars, and each cultivar has at least six replicates. Values are means of all replicates of all cultivar in each group \pm SE. ${ }^{*} t$ test and ANOVA significant difference. ${ }^{*} P<0.05,{ }^{* * P}<0.01$. The results of ANOVA are shown in Additional file 2: Table S2

GHARFLOR1611 (G1611), Tumangmai (TMM), Wanyuan66 (WY66), PENNY; Rht-B1b group: Xuzhou21 (XZ21), Xiaoyan22 (XY22), SAGITTARIO, Wanmai33 (WM33) and Rht-D1b group: Aikang58 (AK58), Zhongmai9 (ZM9), Xinmai9 (XM9), Jimai26 (JM26).

\section{Plant culture and treatments}

Seeds of the wheat were surface-disinfected in $5 \%$ sodium hypochlorite for 10 minutes, then rinsed in distilled water for six times, and soaked in a low-temperature $\left(4{ }^{\circ} \mathrm{C}\right)$ incubator for vernalization 3 days. The vernalized seeds were transferred into germinating box $(15 \times 15 \mathrm{~cm}, 16$ seedlings per box) with filter paper and cultured in sterile distilled water. In addition, replacing $15 \mathrm{ml}$ distilled water every two days. During this period, no mineral nutrients were added. These seedlings were cultured in a growth chamber with $22{ }^{\circ} \mathrm{C} / 18{ }^{\circ} \mathrm{C}$ (day/night), $16 \mathrm{~h} / 8 \mathrm{~h}$ (light/ dark, light intensity, $2000 \mathrm{~lx}$ ), and 50\% humidity.

After 14 days of germination, well-grown wheat seedlings from each cultivar were selected and transferred into a test tube containing $1 / 2$ Hoagland nutrient solution (Fig. 1). The composition of the nutrient solution was as follows: $2 \mathrm{mM} \mathrm{Ca}\left(\mathrm{NO}_{3}\right)_{2} \cdot 4 \mathrm{H}_{2} \mathrm{O}, 3 \mathrm{mM} \mathrm{KNO} \mathrm{KN}_{3}, 1 \mathrm{mM}$ $\mathrm{MgSO}_{4} \cdot 7 \mathrm{H}_{2} \mathrm{O}, 10 \mu \mathrm{M}$ Fe-EDTA, $0.5 \mathrm{mM} \mathrm{NH} \mathrm{H}_{2} \mathrm{PO}_{4}$, $23 \mu \mathrm{M} \mathrm{HBO}_{3}, 1 \mu \mathrm{M} \mathrm{ZnSO}_{4} \cdot 7 \mathrm{H}_{2} \mathrm{O}, 0.15 \mu \mathrm{M}, \mathrm{MnCl}_{2} \cdot 4 \mathrm{H}_{2} \mathrm{O}$, $\mathrm{CuSO}_{4} \cdot 5 \mathrm{H}_{2} \mathrm{O}$ and $0.05 \mu \mathrm{M} \mathrm{Na} \mathrm{MoO}_{4} \cdot 2 \mathrm{H}_{2} \mathrm{O}$. Notably, to avoid failure detection of trace elements, two seedlings were put into each test tube. In addition, the opening of the tube is sealed with plastic film to prevent the evaporation of nutrient solution. Then, these seedlings were transferred to the growth chamber with the same growth parameters for different treatment time.

\section{Time gradient treatment}

Two cultivars were selected for treatment at four time points $(12 \mathrm{~h}, 36 \mathrm{~h}, 60 \mathrm{~h}, 84 \mathrm{~h})$. The treatment time is calculated from the time when the seedlings are placed in a test tube containing nutrient solution to the time when they are removed. At least 6 replicates were performed for each cultivar under each time treatment, with one test tube as a replicate. In addition, test tubes without treatment of seedlings were used as controls and at least 6 replicates were also performed under each time treatment. 

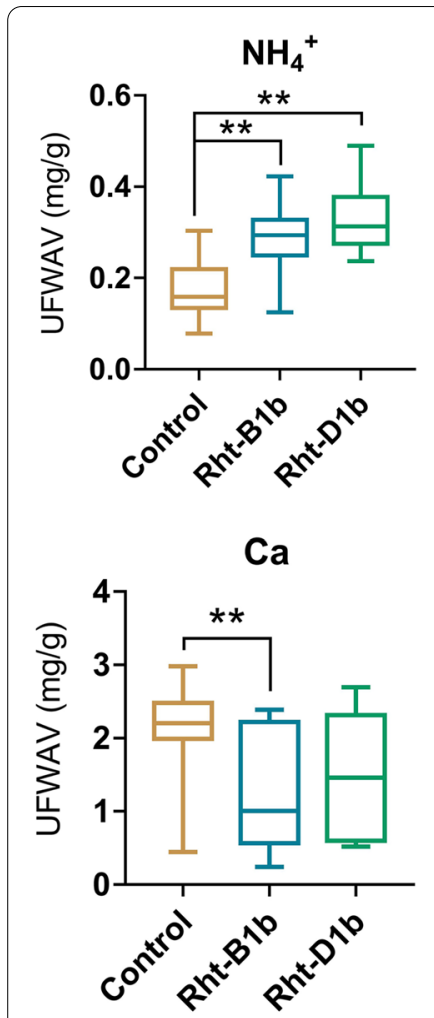

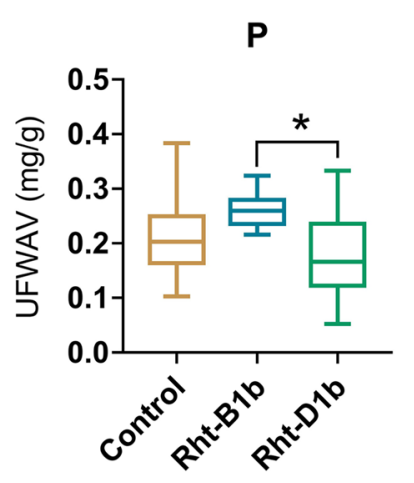

Mn

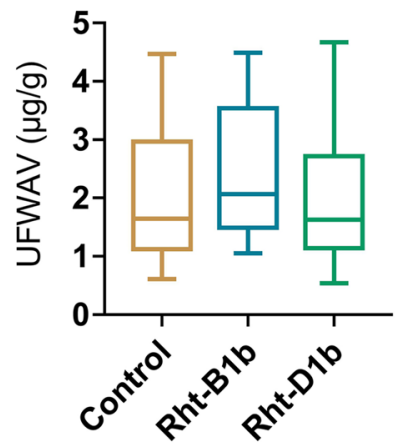

K

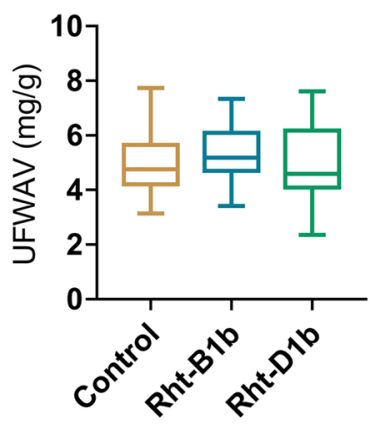

$\mathrm{Zn}$

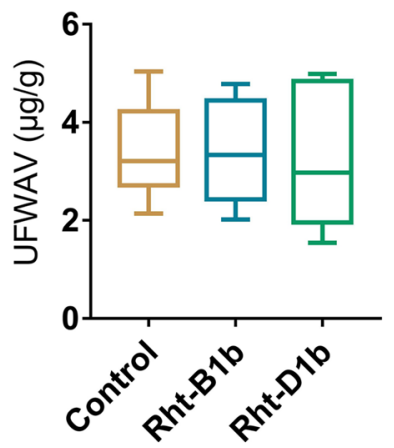

Fig. 6 Effects of high Zn concentration (10 $\mu \mathrm{M})$ on the absorption of mineral elements in wheat containing the Rhts allele. UFWAV: unit fresh weight absorption value. The control group contains seven cultivars, and the Rht-B1b and Rht-D1b groups respectively include four cultivars, and each cultivar has at least six replicates. Values are means of all replicates of all cultivar in each group $\pm \mathrm{SE}$.*t test and ANOVA significant difference. ${ }^{*} \mathrm{P}<0.05,{ }^{*} \mathrm{P}<0.01$. The results of ANOVA are shown in Additional file 2: Table S2

\section{Zn concentration gradient treatment}

In this study, five $\mathrm{Zn}$ concentration gradients of 0 , $0.01,0.1,1,10 \mu \mathrm{M}$ were selected. $\mathrm{Zn}$ concentration was changed by changing the content of $\mathrm{ZnSO}_{4} \cdot 7 \mathrm{H}_{2} \mathrm{O}$ on the basis of $1 / 2$ Hoagland nutrient solution, while the content of other elements remained unchanged. In addition, all treatments and culture conditions were consistent with those described above.

\section{Determination of absorption value of mineral elements}

After treatment, the wheat seedlings were taken out of the test tubes, and the fresh weight of seedlings and the volume of remaining nutrient solution were measured. Next, prepare standard solutions for each element, and then use Flame/Graphite Furnace Atomic Absorption Spectrometer "Z2000" (Hitachi, Japan) and continuous flow analyzer "FLOWSYS" (Systea, Italy) to detect the absorbance value of each element, and finally obtain the standard solution curve and curve equation of each element. Then detect the absorbance value of each element in the test tube of the control group and the treatment group, and calculate the concentration of each element through the curve equation.

Note: the absorbance value of total $\mathrm{Zn}, \mathrm{Mn}, \mathrm{Cu}, \mathrm{Mg}$, $\mathrm{K}$ and $\mathrm{Ca}$ in the nutrient solution in the test tube were measured by Atomic Absorption Spectrometer. Due to the limited detection range of the instrument, the nutrient solution must be diluted 10 times to measure the concentration of $\mathrm{Mg}$, and diluted 100 times to measure the concentration of $\mathrm{K}$ and $\mathrm{Ca}$. The absorbance value of total $\mathrm{NH}_{4}^{+}$and $\mathrm{P}$ in the nutrient solution were measured by continuous flow analyzer, in which the measurement of element $\mathrm{P}$ requires dilution of the nutrient solution by 5 times. The concentrations of all elements in the nutrient solution of the untreated seedlings were as the control.

In order to avoid the influence of the different growth status of wheat seedlings on the measurement results, the absorption value per unit fresh weight was used as the index to evaluate the nutrient absorption capacity of wheat in this study. Unit fresh weight absorption value $($ UFWAV) $=($ control measurement value $\times$ volume - sample measurement value $\times$ volume)/fresh weight. 


\section{Statistical analysis}

Use the software SPSS (IBM SPSS Statistics 23.0) for statistical analysis of the data, and use the analysis of variance (ANOVA) for the significance of each treatment effect and its interaction. When the results of the analysis of variance show a significant difference, the Tukey's HSD test is used to determine the significant difference between the means $(\mathrm{P}<0.05)$.

\section{Supplementary Information}

The online version contains supplementary material available at https://doi. org/10.1186/s13007-021-00805-7.

Additional file 1: Figure S1. The concentration of each element in the control group under different treatment time. Figure S2. The unit fresh weight absorption values of $\mathrm{Mg}, \mathrm{Ca}, \mathrm{Mn}$ and $\mathrm{Zn}$ in two wheat cultivars after $60 \mathrm{~h}$ treatment. Figure S3. Zn absorption values of seven cultivars treated with different $Z n$ concentrations ( $1 \mu \mathrm{M}$ and $10 \mu \mathrm{M})$. Figure S4. Effects of low $\mathrm{Zn}$ concentration $(0-0.1 \mu \mathrm{M})$ on the absorption of mineral elements in wheat containing the Rhts allele.

Additional file 2: Table S1. Fitting function of Pearson correlation analysis between elements. Table S2. Variance analysis of absorption values of various elements for different group cultivar.

\section{Acknowledgements}

We thank the Zhejiang Major Scientific and Technological Project of Agricultural (Upland crop) Breeding (2021 C02064-6) and National Key Research and Development Program of China (No. 2018YFD0200500) for financial support.

\section{Authors' contributions}

All authors contributed to the study conception and design. Material preparation, data collection and analysis were performed by XM, JZ, JZ, TL, QW. The first draft of the manuscript was written by Xiaolong Guo and all authors commented on previous versions of the manuscript. All authors read and approved the final manuscript.

\section{Funding}

This research was supported by Zhejiang Major Scientific and Technological Project of Agricultural (Upland crop) Breeding (2021 C02064-6) and the National Key Research and Development Program of China (No. 2018YFD0200500) to Wei Hua.

\section{Availability of data and materials}

Not applicable.

\section{Declarations}

Ethics approval and consent to participate

Not applicable.

\section{Consent for publication}

Not applicable.

\section{Competing interests}

The authors declare that they have no competing interests.

Received: 28 July 2021 Accepted: 29 September 2021

Published online: 12 October 2021

\section{References}

1. Galloway JN, Townsend AR, Erisman JW, Bekunda M, Cai Z, Freney JR, Martinelli LA, Seitzinger SP, Sutton MA. Transformation of the nitrogen cycle: recent trends, questions, and potential solutions. Science. 2008;320:889-92

2. Bennett EM, Carpenter SR, Caraco NF. Human impact on erodable phosphorus and eutrophication: a global perspective: increasing accumulation of phosphorus in soil threatens rivers, lakes, and coastal oceans with eutrophication. Bioscience. 2001;51:227-34.

3. Ju XT, Xing GX, Chen XP, Zhang SL, Zhang LJ, Liu XJ, Cui ZL, Yin B, Christie $P$, Zhu ZL, et al. Reducing environmental risk by improving $N$ management in intensive Chinese agricultural systems. Proc Natl Acad Sci USA. 2009;106:3041-6.

4. Palmgren MG, Clemens S, Williams LE, Krämer U, Borg S, Schjørring JK, Sanders D. Zinc biofortification of cereals: problems and solutions. Trends Plant Sci. 2008;13:464-73.

5. Tansley Cl, No R. 111: possible roles of zinc in protecting plant cells from damage by reactive oxygen species. New Phytol. 2000;146:185-205.

6. Lacerda JS, Martinez HEP, Pedrosa AW, Clemente JM, Santos RHS, Oliveira $\mathrm{GL}$, Jifon JL. Importance of zinc for arabica coffee and its effects on the chemical composition of raw grain and beverage quality. Crop Sci. 2018;58:1360-70.

7. Rios JJ, Garcia-Ibañez P, Carvajal M. The use of biovesicles to improve the efficiency of $\mathrm{Zn}$ foliar fertilization. Colloids Surf B Biointerfaces. 2019;173:899-905.

8. Xie R, Zhao J, Lu L, Ge J, Brown PH, Wei S, Wang R, Qiao Y, Webb SM, Tian S. Efficient phloem remobilization of $Z n$ protects apple trees during the early stages of Zn deficiency. Plant Cell Environ. 2019;42:3167-81.

9. Mattiello EM, Ruiz HA, Neves JCL, Ventrella MC, Araújo WL. Zinc deficiency affects physiological and anatomical characteristics in maize leaves. J Plant Physiol. 2015;183:138-43.

10. Singh A, Singh NB, Afzal S, Singh T, Hussain I. Zinc oxide nanoparticles: a review of their biological synthesis, antimicrobial activity, uptake, translocation and biotransformation in plants. J Mater Sci. 2018;53:185-201.

11. Cakmak I, Pfeiffer WH, McClafferty B. Review: biofortification of durum wheat with zinc and iron. Cereal Chem. 2010:87:10-20.

12. Rehman A, Faroog M, Ozturk L, Asif M, Siddique KHM. Zinc nutrition in wheat-based cropping systems. Plant Soil. 2018;422:283-315.

13. Rossi L, Fedenia LN, Sharifan $H, M a X$, Lombardini L. Effects of foliar application of zinc sulfate and zinc nanoparticles in coffee (Coffea arabica L.) plants. Plant Physiol Biochem. 2019;135:160-6.

14. Stewart ZP, Paparozzi ET, Wortmann CS, Jha PK, Shapiro CA. Effect of foliar micronutrients ( $\mathrm{B}, \mathrm{Mn}, \mathrm{Fe}, \mathrm{Zn}$ ) on maize grain yield, micronutrient recovery, uptake, and partitioning. Plants. 2021;10(3):528.

15. Humaira ST, Shah HU, Ullah S, Javid M. Zinc effect on growth rate, chlorophyll, protein and mineral contents of hydroponically grown mungbeans plant (Vigna radiata). Arab J Chem. 2017;10:S1802-7.

16. Di Baccio D, Kopriva S, Sebastiani L, Rennenberg H. Does glutathione metabolism have a role in the defence of poplar against zinc excess? New Phytol. 2005;167:73-80.

17. Jain R, Srivastava S, Solomon S, Shrivastava AK, Chandra A. Impact of excess zinc on growth parameters, cell division, nutrient accumulation, photosynthetic pigments and oxidative stress of sugarcane (Saccharum spp.). Acta Physiol Plant. 2010;32:979-86.

18. Kaya C, Higgs D, Burton A. Plant growth, phosphorus nutrition, and acid phosphatase enzyme activity in three tomato cultivars grown hydroponically at different zinc concentrations. J Plant Nutr. 2000;23:569-79.

19. Mahmooduzzafar KT, labal M, Sairam RK. Zinc-induced changes in morpho-physiological and biochemical parameters in Artemisia annua. Biol Plantarum. 2004;48:255-60.

20. Ova EA, Kutman UB, Ozturk L, Cakmak I. High phosphorus supply reduced zinc concentration of wheat in native soil but not in autoclaved soil or nutrient solution. Plant Soil. 2015;393:147-62.

21. Nie Z, Zhao P, Shi H, Wang Y, Qin S, Liu H. Nitrogen supply enhances zinc uptake and root-to-shoot translocation via up-regulating the expression of TaZIP3 and TaZIP7 in winter wheat (Triticum aestivum). Plant Soil. 2019:444:501-17.

22. Reddy KR, Saxena MC, Pal UR. Effect of iron and manganese on Zn absorption and translocation in soybean seedlings. Plant Soil. 1978;49:409-15.

23. Loddo S, Gooding M. Semi-dwarfing (Rht-B1b) improves nitrogen-use efficiency in wheat, but not at economically optimal levels of nitrogen availability. Cereal Res Commun. 2012;40:116-21. 
24. Gooding MJ, Fan M, McGrath SP, Shewry PR, Zhao F. Contrasting effects of dwarfing alleles and nitrogen availability on mineral concentrations in wheat grain. Plant Soil. 2012;360:93-107.

25. Pingali PL. Green Revolution: Impacts, limits, and the path ahead. Proc Natl Acad Sci USA. 2012;109:12302-8.

26. Zhang C, Gao L, Sun J, Jia J, Ren Z. Haplotype variation of Green Revolution gene Rht-D1 during wheat domestication and improvement. J Integr Plant Biol. 2014;56:774-80.

27. Fan MS, Zhao FJ, Fairweather-Tait SJ, Poulton PR, Dunham SJ, McGrath SP. Evidence of decreasing mineral density in wheat grain over the last 160 years. J Trace Elem Med Biol. 2008;22:315-24.

28. Rengel Z, Graham RD. Wheat genotypes differ in Zn efficiency when grown in chelate-buffered nutrient solution. Plant Soil. 1995;176:307-16.

29. Chen X-X, Zhang W, Wang Q, Liu Y-M, Liu D-Y, Zou C-Q. Zinc nutrition of wheat in response to application of phosphorus to a calcareous soil and an acid soil. Plant Soil. 2019;434:139-50.

30. Medici A, Marshall-Colon A, Ronzier E, Szponarski W, Wang R, Gojon A, Crawford NM, Ruffel S, Coruzzi GM, Krouk G. AtNIGT1/HRS1 integrates nitrate and phosphate signals at the Arabidopsis root tip. Nat Commun. 2015;6:6274.

31. Hu B, Jiang Z, Wang W, Qiu Y, Zhang Z, Liu Y, Li A, Gao X, Liu L, Qian Y, et al. Nitrate-NRT1.1B-SPX4 cascade integrates nitrogen and phosphorus signalling networks in plants. Nat Plants. 2019;5:401-13.

32. Li S, Tian Y, Wu K, Ye Y, Yu J, Zhang J, Liu Q, Hu M, Li H, Tong Y, et al. Modulating plant growth-metabolism coordination for sustainable agriculture. Nature. 2018;560:595-600
33. Xu G, Fan X, Miller AJ. Plant nitrogen assimilation and use efficiency. Annu Rev Plant Biol. 2012;63:153-82.

34. Strullu-Derrien C, Selosse MA, Kenrick P, Martin FM. The origin and evolution of mycorrhizal symbioses: from palaeomycology to phylogenomics. New Phytol. 2018;220:1012-30.

35. Heckman DS, Geiser DM, Eidell BR, Stauffer RL, Kardos NL, Hedges SB. Molecular evidence for the early colonization of land by fungi and plants. Science. 2001;293:1129-33.

36. Cakmak I, Marschner $\mathrm{H}$. Increase in membrane permeability and exudation in roots of zinc deficient plants. J Plant Physiol. 1988;132:356-61.

37. Shri PU, Pillay V. Excess of soil zinc interferes with uptake of other micro and macro nutrients in Sorghum bicolor (L.) plants. Ind J Plant Physiol. 2017:22:304-8.

38. Foy CD, Chaney RL, White MC. The physiology of metal toxicity in plants. Annu Rev Plant Biol. 1978;29:511-66.

39. Singh BR, Steenberg K. Plant response to micronutrients. Plant Soil. 1974;40:655-67.

40. Lakshmanan R, Prasad R, Jain MC. Yield and uptake of micronutrients by rice as influenced by duration of variety and nitrogen fertilization. Arch Agron Soil Sci. 2005;51:1-14.

\section{Publisher's Note}

Springer Nature remains neutral with regard to jurisdictional claims in published maps and institutional affiliations.
Ready to submit your research? Choose BMC and benefit from:

- fast, convenient online submission

- thorough peer review by experienced researchers in your field

- rapid publication on acceptance

- support for research data, including large and complex data types

- gold Open Access which fosters wider collaboration and increased citations

- maximum visibility for your research: over 100M website views per year

At BMC, research is always in progress.

Learn more biomedcentral.com/submissions 